\title{
Analisis Pembentukan Portofolio Optimal dan Penentuan Nilai Risiko pada Saham Syariah
}

\section{Analysis of optimal portfolio formation and risk value determination on Islamic stocks}

\section{Ajeng Defi Aprilia}

Program Studi D4 Keuangan Syariah, Politeknik Negeri Bandung

E-mail: ajengdefiapr@gmail.com

\section{Ade Ali Nurdin}

Jurusan Akuntansi, Politeknik Negeri Bandung

E-mail: ade.nurdin@polban.ac.id

\section{Muhamad Umar Mai}

Jurusan Akuntansi, Politeknik Negeri Bandung

E-mail: umar.mai@polban.ac.id

\begin{abstract}
The purpose of this research is to determine the optimal porffolio formation in Islamic stocks on the Jakarta Islamic Index (JII) which is listed on the Indonesia Stock. Exchange with a single model. Then measure the risk value that may occur and be accepted by investors using the $V$ alue at Risk (VaR) method with the Exponentially Weighted Moving Average (EWMA) approach. By using the Single Index Model, 5 stocks are selected and form an optimal portfolio, namely ASII, ICBP, TLKM, UNTR and UNVR.
\end{abstract}

Keywords: optimal portfolio, Islamic stocks, risk

\section{Pendahuluan}

Investasi merupakan sebuah cara untuk mendapatkan keuntungan pun memiliki risiko. Berinvestasi dalam saham mengandung unsur ketidakpastian atau mempunyai risiko tinggi. Ada dua jenis risiko di dalam kegiatan investasi, yaitu risiko sistematis dan non-sistematis risiko. Risiko secara sistematis adalah risiko yang terjadi karena faktor di luar perusahaan, seperti inflasi. Sementara risiko non-sistematis adalah risiko yang terjadi karena faktor buruk yang terjadi dalam perusahaan. Untuk mengurangi tingkat risiko ditanggung oleh investor, kita dapat melakukan penyebaran risiko ke dalam beberapa aset atau disebut diversifikasi. Diversifikasi terbentuk untuk membentuk sebuah portofolio. Portofolio adalah satu set investasi. Dengan membentuk sebuah portofolio, kita dapat mengurangi kerugian karena ketika nilai dari satu sekuritas menurun, masih ada saham lain yang naik.

Kesulitan untuk membentuk portofolio yang optimal menjadi salah satu kendala yang sering dihadapi investor sehingga perlu untuk menggunakan beberapa data sebagai masukan dalam penghitungan untuk membentuk portofolio. Untuk alasan itu, diperlukan model perhitungan untuk memfasilitasi untuk membentuk portofolio. Salah satu model perhitungan portofolio adalah model Index Tunggal. Model Index Tunggal dikembangkan oleh Sharpe, yang digunakan untuk menyederhanakan kalkulasi dalam metode Markowitz. Selain itu, akan lebih baik apabila investor dan manajer portofolio mengetahui tingkat risiko yang dapat mereka tanggung. Volatilitas merupakan salah satu komponen penting dalam pengoptimalan portofolio. Untuk mendapatkan 
portofolio yang optimal dan kemungkinan risiko yang akan ditanggung digunakan pula perhitungan volatilitas dengan Metode Value at Risk dengan model Exponentially Weighted Moving Average (EWMA).

Penelitian ini menggunakan data dari Jakata Islamic Index (JII) dikarenakan JII merupakan benchmark saham syariah di Indonesia. Jakarta Islamic Index (JI) terdiri dari 30 saham yang dipilih oleh Dewan Syariah nasional (DSN) per semester, tepat setiap bulan Januari dan Juni. Secara khusus, saham yang tercantum dalam kriteria Jakata Islamic Index (JII) adalah mereka yang operasinya tidak mengandung ribawi, modal perusahaan juga bukan mayoritas utang. Jadi ini saham Jakata Islamic Index (JII) umumnya memiliki struktur modal yang sehat dan tidak dibebani dengan bunga hutang yang berlebihan, dengan kata lain Rasio hutang terhadap ekuitas masih proporsional sehingga sangat menjanjikan untuk investasi jangka panjang. Manajemennya juga dianggap transparan dan kredibel serta menghormati para pemegang sahamnya.

\section{Kajian Pustaka}

\subsection{Portofolio Modern}

Pada awal tahun 1956, diperkenalkan pertama kali oleh Harry Markowitz sebuah teori portfolio. Dalam teori tersebut, dinyatakan terdapat beberapa hal tentang perhitungan keuntungan, risiko, dan bagaimana sebuah portofolio terbentuk. Menurut Jogiyanto (2013), Portfolio merupakan kombinasi dari gabungan saham untuk mendapatkan keuntungan yang maksimal.

\subsection{Model Indeks Tunggal}

Sharpe mengembangkan sebuah model perhitungan yang lebih sederhana dari perhitungan Markowitz yaitu model index tunggal. Dalam perhitunannya terdapat sebuah parameter input yang diperlukan dalam perhitungan model Markowitz. Menurut Zubir (2013) Pengembalian dalam risiko sekuritas ataupun portofolio dapat dihitung dan diukur oleh model index tunggal. Asumsi dari model ini adalah bahwa apabila terjadi pergerakan dari saham itu terkait dengan apa yang terjadi di pasar dan menyebabkan terjadinya pergerakan di pasar. Dalam hal ini, apabila pasar bergerak ke atas naik, dapat diartikan bahwa keadaan permintaan dari saham meningkat, maka akan bergerak sama dengan harga saham di pasar yaitu akan terjadi kenaikan juga. Sebaliknya, jika terjadi pergerakan pasar ke bawah, maka akan diikuti dengan harga saham yang akan ikut turun mengikuti pasarnya. Dengan demikian, saham terdapat hubungannya dengan pasar. Sebuah Portofolio akan dikatakan optimal apabila didalamnya terdapat aset yang mempunyai risiko ERB tinggi. Aset dengan nilai ERB yang rendah tidak diikutkan ke dalam portofolio yang dikatakan optimal. Titik $\mathrm{C} *$ titik cut off merupakan pembatas dan sebagai penentu portofolio yang optimal.

\subsection{Jakarta Islamic Index (JII)}

Bursa Efek Indonesia (BEI) dan PT Danareksa Investment Management (DIM) melakukan kerjasama pada tahun 2000 tepatnya 3 Juli dengan terobosan baru merintih sebuah benchmark yang berbasis syariah dinamakai Jakarta Islamic Index (JII). Dengan adanya indeks tersebut akan menjadi sebuah tolak ukur bagaimana kinerja saham dengan berbasis pada hukum syariah. Selain itu, sebagai salah satu cara dalam mengembangkan pasar modal berbasis syariah.

Untuk menentukan saham yang termasuk dalam perhitungan Jakarta Islamic Indeks (JII), proses seleksi adalah sebagai berikut:

a) Saham yang dipilih berdasarkan daftar Surat Berharga Syariah (DES) yang diterbitkan oleh Bapepam-LK.

b) Memilih 60 saham dari daftar efek Syariah berdasarkan urutan kapitalisasi pasar terbesar dalam 1 tahun terakhir.

c) Dari 60 perusahaan dipilih 30 perusahaan berdasarkan likuiditas, nilai transaksi di pasar reguler dalam 1 tahun terakhir 


\subsection{Exponentially Weighted Moving Average (EWMA)}

Tahun 1989 Model Exponentially Weighted Moving Average (EWMA) diturunkan oleh JP Morgan untuk kerangka metrik risiko mereka dari distribusi Gaussian. Model EWMA ini menghitung volatilitas yang lebih ditekankan pada return saham yang paling baru. Alasan di balik perhitungan dengan model ini adalah bahwa pergerakan harga saham baru-baru ini adalah prediktor terbaik dalam bentuk prediksi dalam pergerakan harga sekuritass di masa depan. Model ini merupakan perbaikan dari model dengan volatilitas sederhana. Model EWMA memberikan perkiraan volatilitas untuk hari $t+1$ dengan rumus

$$
\sigma_{t}=\sqrt{\lambda \sigma_{t-1}^{2}+(1-\lambda) R_{t-1}^{2}}
$$

Dimana,

$$
\lambda(0<\lambda<0)
$$

Paramater model yang dinamakan decay factor. Menurut Dian (2014) Decay factor mempengaruhi volatilitas, nilai decay factor yang semakin tinggi pada sebuah data imbal hasil dapat diartikan dengan pengaruh volatilitas sebelumnya atau tingkat persistence nya semakin besar, namun untuk informasi imbal hasil pasar terakhir semakin tidak reaktif. Sebaliknya nilai decay factor yang semakin kecil membuat data imbal hasil semakin reaktif volatilitasnya.

\subsection{Value at Risk (VaR)}

Value at Risk (VaR) telah menjadi alat populer yang digunakan manajer portofolio untuk menilai, mengelola, dan mengontrol risiko. VaR merupakan konsep statistik yang merujuk kerugian tertinggi yang mungkin timbul sebagai akibat dari variasi tingkat suku bunga, nilai tukar dan harga saham yang relevan dengan portofolio atau aset dengan mengambil interval keyakinan. Metode VaR ditampilkan dalam rumus sebagai berikut:

Dimana,

$$
\mathrm{VaR}=\alpha_{P} \sigma_{P} P \sqrt{t}
$$

M : Nilai pasar portofolio

$\alpha \quad$ : Tingkat keyakinan $(\alpha=0.01,0,05,0,10)$

$\sigma \quad:$ Standar Deviasi Portofolio

t $\quad$ : Durasi

\subsection{Kupiec POF (1995) test (Propotion of Failures)}

Kupiec POF test (Propotion of Failures) digunakan untuk memeriksa apakah jumlah pengecualian sudah sesuai dengan tingkat kepercayaan. Alasan penggunaan POF Test (Propotion of Failures) untuk menyatakan apakah model VaR dalam peramalan kerugiannya sudah sesuai dengan yang diramalkan. Likelihood ratio test "LR" digambarkan dengan rumus:

$$
\zeta L R=-2 \ln \left[(1-p)^{T-N} \times p^{N}\right]+2 \ln \left\{\left[1-\left(\frac{N}{T}\right)\right]^{(T-N)}\left(\frac{N}{T}\right)^{N}\right\}
$$

\section{Metode Penelitian}

Metode penelitian yang digunakan adalah penelitian deskriptif dengan pendekatan kuantitatif. Data diolah menggunakan Microsoft Excel 2016. Pengambilan sampel berdasarkan metode purposive sampling. Sampel yang diambil dari penelitian ini adalah saham yang selalu masuk ke dalam kelompok Jakarta Islamic Index (JII) selama periode penelitian. Langkah-langkah Analisis Model Indeks Tunggal: a) Pengambilan data Closing price dari Jakarta Islamic Index (JII) Periode 2014-2018; 
b) Menghitung Return dan Risiko saham.; dan c) Menghitung expected return, standar deviasi, varians, alfa, beta, ERBi, Cut Off Point dan proporsi dana untuk pembentukan portofolio optimum. Setelah itu dilakukan tahapan sebagai berikut:

a) Melakukan uji stationeritas, normalitas dan heteroskedastisitas

- Uji Stationeritas

- Uji Normalitas

- Uji Heteroskedastisitas

b) Perhitungan VaR pendekatan EWMA

c) Uji Backtesting

\section{Hasil dan Pembahasan (Font: Garamound, size 13)}

Saham dikategorikan ke dalam kandidat portofolio optimal apabila diketahui dari expected return yang diperoleh pada setiap saham. Jika saham memiliki expected return negatif, maka saham tidak termasuk dalam penghitungan kategori portofolio yang optimal. Di sisi lain, jika saham memiliki expected return positif, maka dapat masuk ke dalam kategori portofolio optimal.

\subsection{Hasil Pembentukan Potofolio Optimal Model Indeks Tunggal}

\section{Menghitung Expected Return dan Standar Deviasi}

Tabel 1. Hasil Perhitungan Expected Return dan Standar Deviasi

\begin{tabular}{|c|c|r|r|}
\hline No & KODE & E(Ri) & $\sigma$ \\
\hline 1 & ADRO & 0,000507639 & 0,028971214 \\
\hline 2 & AKRA & 0,000216542 & 0,021605195 \\
\hline 3 & ASII & 0,000349556 & 0,019636157 \\
\hline 4 & BSDE & 0,000231223 & 0,022555992 \\
\hline 5 & ICBP & 0,000809454 & 0,043517513 \\
\hline 6 & INDF & 0,000273785 & 0,018667608 \\
\hline 7 & KLBF & 0,000349679 & 0,019431483 \\
\hline 8 & LPKR & $-0,000822971$ & 0,021486134 \\
\hline 9 & LSIP & $-0,000062180$ & 0,024465124 \\
\hline 10 & PGAS & $-0,000238350$ & 0,027730438 \\
\hline 11 & SMGR & 0,000087724 & 0,022849012 \\
\hline 12 & TLKM & 0,000595156 & 0,016472934 \\
\hline 13 & UNTR & 0,000575529 & 0,023472860 \\
\hline 14 & UNVR & 0,000594180 & 0,016382709 \\
\hline
\end{tabular}

Sumber: Data Diolah

Dari hasil perhitungan terdapat 14 saham yang memiliki expected return tertinggi yang dimiliki oleh ICBC dengan nilai 0.000809454, sedangkan terdapat 3 saham yang memiliki expected returm negatif yaitu, LPKR, LSIP dan PGAS. Jadi, yang masuk ke dalam kategori portofolio optimal adalah ADRO, AKRA, ASII, BSDE, ICBP, INDF, KLBF, SMGR, TLKM, UNTR dan UNVR.

\section{Menghitung Alfa, Beta, variance Residual}

Tabel 2. Hasil perhitungan alpha, beta, dan Variance Residual 


\begin{tabular}{|c|c|r|r|r|}
\hline No & KODE & \multicolumn{1}{c|}{$\alpha$} & \multicolumn{1}{c|}{$\beta$} & $\sigma_{\text {ei }}$ \\
\hline 1 & ADRO & 0,000055975 & 1,354994227 & 0,000986498 \\
\hline 2 & AKRA & $-0,000042925$ & 0,778403785 & 0,000515352 \\
\hline 3 & ASII & $-0,000128854$ & 1,435231350 & 0,000550690 \\
\hline 4 & BSDE & $-0,000290767$ & 1,565973524 & 0,000705336 \\
\hline 5 & ICBP & 0,000815164 & $-0,017128596$ & 0,001893797 \\
\hline 6 & INDF & $-0,000143988$ & 1,253321310 & 0,000474389 \\
\hline 7 & KLBF & $-0,000033156$ & 1,148505142 & 0,000483313 \\
\hline 8 & SMGR & $-0,000393073$ & 1,442393673 & 0,000688841 \\
\hline 9 & TLKM & 0,000212332 & 1,148473269 & 0,000377082 \\
\hline 10 & UNTR & 0,000143904 & 1,294878446 & 0,000685373 \\
\hline 11 & UNVR & 0,000224512 & 1,109006967 & 0,000366976 \\
\hline
\end{tabular}

Sumber: Data Diolah

Berdasarkan tabel 4.3 di atas, diketahui saham dengan nilai alpha tertinggi dimiliki oleh ICBP dengan tingkat (0.000815164) atau sebesar 0,082\%. Sedangkan untuk beta tertinggi didapatkan oleh BSDE dengan tingkat (1.565973524). Alpha menilai bagaimana pengaruh return pasar terhadap return saham baik independen atau tidak. Beta mengukur seberapa besar pengaruh dari return pasar terhadap return saham. Semakin besar nilai beta, maka semakin sensitive return saham terhadap perubahan return pasar. Apabila beta saham $>1$ berarti saham tersebut sensitive terhadap perubahan pasar, sebaliknya, jika $<1$, maka tidak berpengaruh banyak terhadap perubahan pasar.

Dalam indeks Jakarta Islamic Index (JII) saham yang memiliki sensitifitas terhadap perubahan pasar atau memiliki beta $>1$ antara lain UNVR (1.109006967), TLKM (1.148473269), KLBF (1.148505142), INDF (1.253321310), UNTR (1.294878446), ADRO (1.354994227), ASII (1.435231350), SMGR (1.442393673), dan BSDE (1.565973524).

Sisanya memiliki nilai $<1$ yang berarti tidak dipengaruhi oleh perubahan return pasar yaitu ICBP (-0.017128596) dan AKRA (.0.778403785). V ariance residual merupakan risiko unik yang bisa dikurangi dengan melakukan diversifikasi. Dalam indeks ini variance terendah didapatkan oleh UNVR (0.000366976) dan yang tertinggi adalah ICBP (0.001893797)

\section{Menghitung Nilai ERBi dan Cut Off Point sebagai kandidat portofolio optimal}

Berikut merupakan perhitungan nilai ERB dan Cut Off Point.

Tabel 3. Hasil perhitungan nilai ERB dan Cut Off Point:

\begin{tabular}{|c|c|c|c|l|}
\hline No & KODE & ERB & $C^{*}$ & Kesimpulan \\
\hline 1 & ADRO & 0,000100146 & 0,00026 & Tidak Optimal \\
\hline 2 & AKRA & 0,000012929 & 0,00026 & Tidak Optimal \\
\hline 3 & ASII & 0,000145943 & 0,00026 & Optimal \\
\hline 4 & BSDE & 0,000027610 & 0,00026 & Tidak Optimal \\
\hline 5 & ICBP & 0,000605841 & 0,00026 & Optimal \\
\hline 6 & INDF & 0,000070172 & 0,00026 & Tidak Optimal \\
\hline 7 & KLBF & 0,000146066 & 0,00026 & Tidak Optimal \\
\hline 8 & TLKM & 0,000391543 & 0,00026 & Optimal \\
\hline 9 & UNTR & 0,000371916 & 0,00026 & Optimal \\
\hline 10 & UNVR & 0,000390567 & 0,00026 & Optimal \\
\hline
\end{tabular}

Sumber: Data Diolah

\section{Menghitung nilai ERB dan Ci}

Perhitungan nilai ERB dan Ci untuk mendapatkan nilai $C^{*}$ tertinggi dari kombinasi saham 
ada pada tabel 3 .

a) Menentukan nilai Cut Off Point

Nilai Cut Off Point ditentukan dari besarnya nilai maksimum $\mathrm{Ci}$ dari semua nilai Ci setiap saham.

b) Penentuan Saham Kandidat Portofolio Optimal

Berdasarkan hasil perhitungan pada tabel 4.3 menghasilkan sebanyak 5 perusahaan yang menjadi kandidat saham dengan portofolio maksimum. Kriteria saham dengan portofolio optimal merupakan saham yang memiliki nilai ERB $>$ C* $(0,00025516)$

\section{Menentukan Proporsi Dana Portofolio Optimal}

Berikut merupakan perhitungan proporsi dana portofolio optimal:

Tabel 4. Proporsi Dana Portofolio Optimal

\begin{tabular}{|c|c|c|c|c|}
\hline No & KODE & $\mathrm{Zi}$ & Wi & $\%$ \\
\hline 1 & ASII & 0.297260000 & 0.22092 & $22.09 \%$ \\
\hline 2 & ICBP & 0.003130000 & 0.00233 & $0.23 \%$ \\
\hline 3 & TLKM & 0.415368457 & 0.30870 & $30.87 \%$ \\
\hline 4 & UNTR & 0.220581185 & 0.16394 & $16.39 \%$ \\
\hline 5 & UNVR & 0.409191544 & 0.30411 & $30.41 \%$ \\
\hline & & 1.345531185 & 1 & $100.00 \%$ \\
\hline
\end{tabular}

Sumber: data diolah

Menurut tabel 4, sekuritas dengan proporsi dana terbesar adalah TLKM dengan komposisi 30,87\%. Lalu, saham dengan proporsi dana terkecil adalah ICBP dengan komposisi $0,02 \%$

\section{Mencari Expected.Return.Portofolio}

Setelah mengetahui bentuk proporsi portofolio, selanjutnya akan mengukur tingkat keuntungan yang diharapkan pada setiap portofolio saham.

Tabel 5. Expected Return Jakarta Islamic Indeks (JII)

Periode Januari 2014 - Desember 2018

\begin{tabular}{|c|c|c|c|c|c|c|}
\hline No & KODE & $\mathrm{Zi}$ & Wi & $\alpha$ & api & $\beta \mathrm{pi}$ \\
\hline 1 & ASII & 0.297260000 & 0.22092390 & -0.00012885 & -0.00002847 & 0.31707691 \\
\hline 2 & ICBP & 0.003130000 & 0.00232622 & 0.00081516 & 0.00000190 & -0.00003984 \\
\hline 3 & TLKM & 0.415368457 & 0.30870221 & 0.00021233 & 0.00006555 & 0.35453624 \\
\hline 4 & UNTR & 0.220581185 & 0.16393614 & 0.00014390 & 0.00002359 & 0.21227737 \\
\hline 5 & UNVR & 0.409191544 & 0.30411153 & 0.00022451 & 0.00006828 & 0.33726180 \\
\hline & & 1.345531185 & 1 & 0.000130844 & 0.000130844 & 1.22111248 \\
\hline \multicolumn{3}{|c|}{$E(\mathrm{Rm})$} & \multicolumn{4}{|c|}{0.000333333} \\
\hline \multicolumn{3}{|c|}{$E(R p)$} & \multicolumn{4}{|c|}{0.000537881} \\
\hline
\end{tabular}

Sumber: Data diolah, Microsoft Excel

Terdapat hasil tersebut jadi diketahui bahwa return pada portofolio optimal Jakarta Islamic Index $(0,000537881)$ jika dibandingkan dengan return pasar $(0,000333333)$ maka lebih besar. Dapat disimpulkan apabila portofolio Jakarta Islamic Indeks (JII) punya sebuah nilai yang lebih baik dibandingkan dengan pasarnya.

\subsection{Uji Data Saham}

\section{Uji Stationeritas}

Augmented Dickey Fuller (ADF) test merupakan uji stationer data yang digunakan dalam penelitian ini. Tingkat kepercayaan yang digunakan pada Augmented Dickey Fuller (ADF) test adalah 
$5 \%$ atau 0,05 . Data akan dikatakan stationer apabila nilai yang didapatkan dari hasil Augmented Dickey Fuller (ADF) test lebih kecil dari 0.05. Apabila hasil pada nilai Augmented Dickey Fuller (ADF) test lebih besar dari 0.05 maka diperlukan differencing (Buchdadi : 2008).

Tabel 6. Hasil Tes Uji Stationeritas / ADF Test Saham TLKM

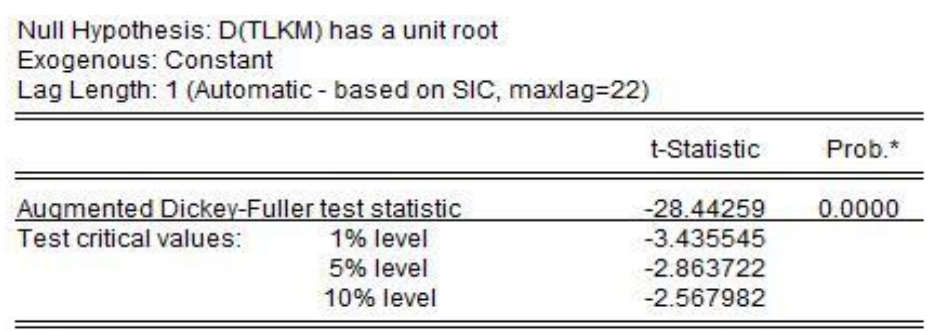

*MacKinnon (1996) one-sided p-values.

Augmented Dickey-Fuller Test Equation

Dependent Variable: D(TLKM,2)

Method: Least Squares

Date: $05 / 13 / 19$ Time: $21: 39$

Sample (adjusted): 41212

Included observations: 1209 after adjustments

\begin{tabular}{lrlrr}
\hline \hline \multicolumn{1}{c}{ Variable } & Coefficient & Std. Error & t-Statistic & Prob. \\
\hline \hline \multicolumn{1}{c}{ D(TLKM(-1)) } & -1.182181 & 0.041564 & -28.44259 & 0.0000 \\
D(TLKM(-1),2) & 0.118464 & 0.028583 & 4.144545 & 0.0000 \\
\multicolumn{1}{c}{ C } & 1.581909 & 1.651756 & 0.957713 & 0.3384 \\
\hline \hline R-squared & 0.535251 & Mean dependent var & 0.041356 \\
Adjusted R-squared & 0.534480 & S.D. dependent var & 84.13097 \\
S.E. of regression & 57.40173 & Akaike info criterion & 10.94050 \\
Sum squared resid & 3973720. & Schwarz criterion & 10.95315 \\
Log likelihood & -6610.535 & Hannan-Quinn criter. & 10.94527 \\
F-statistic & 694.4744 & Durbin-Watson stat & 2.014540 \\
Prob(F-statistic) & 0.000000 & & & \\
\hline \hline
\end{tabular}

Data yang digunakan merupakan data harian pada Jakarta Islamic Index (JII) periode 20142018. Nilai ADF Test untuk saham TLKM senilai -28.44259, lebih kecil dibandingkan dengan nilai CR 5\% sebesar $-2,863722$ dan memiliki nilai probabilitas 0,000 atau lebih kecil dari 0,05. Oleh karena itu, dapat disimpulkan bahwa saham TLKM bersifat stasioner. Pada Tabel 7 di bawah ini adalah rangkuman hasil ADF test dari saham portofolio optimal dari Jakarta Islamic Indeks (III).

Tabel 7. Hasil Uji Stationeritas / ADF Test Saham Jakarta Islamic Index (JII)

\begin{tabular}{|c|c|c|c|c|c|}
\hline No & KODE & ADF TEST & Critical Value & Prob & Kesimpulan \\
\hline 1 & ASII & -26.82610 & -2.286372 & 0.000 & Stationer \\
\hline 2 & ICBP & -24.47188 & -2.863726 & 0.000 & Stationer \\
\hline 3 & TLKM & -28.44259 & -2.863722 & 0.000 & Stationer \\
\hline 4 & UNTR & -27.60873 & -28.63722 & 0.000 & Stationer \\
\hline 5 & UNLV & -38.39426 & -2.863720 & 0.000 & Stationer \\
\hline
\end{tabular}

\section{Uji Normalitas}

Uji Jarque Bera digunakan dalam penelitian ini untuk melihat data apakah terdistribusi normal atau tidak dengan mengukur perbedaan dari skewness dan kurtosis dari data penelitian. (Winarno, 2015). Data dikatakan normal apabila nilai Jarque Bera lebih kecil dibandingkan dengan nilai $\chi^{2}$ (ChiSquare) dengan $\alpha=0,05 \mathrm{dan} \mathrm{df}=2$, dan sebaliknya. Data tidak normal dapat dilakukan penyesuaian dengan Koef Cornish-Fisher Expansion ( $\left.\alpha^{\prime}\right)$ 


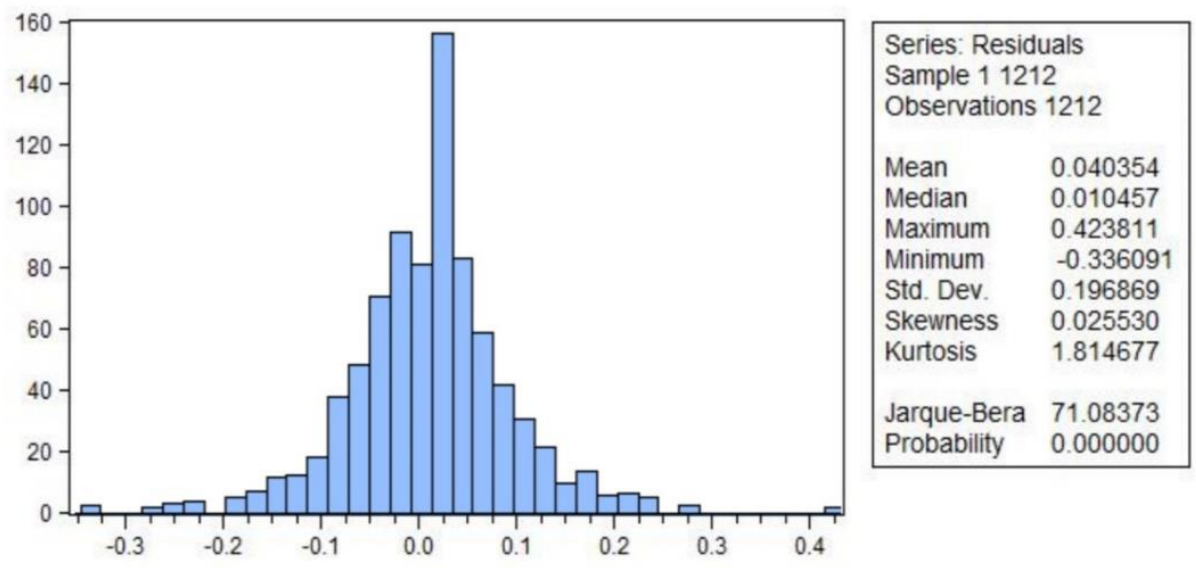

Gambar 1. Hasil Uji Normalitas Saham TLKM

Nilai Jarque Bera yang diperoleh oleh saham TLKM sebesar 71.08373 dengan probabilitas 0,000 pada hasil uji normalitas. Dapat diartikan bahwa saham TLKM memiliki nilai lebih besar dari nilai Chi Square 9,48773 dan lebih kecil dari nilai probabilitas 0,05. Oleh karena itu, dapat disimpulkan bahwa saham TLKM tidak berdistribusi normal. Artinya alpha dari saham TLKM harus dikoreksi dan mendapatkan nilai alpha yang baru.

Tabel 8. Hasil Uji Normalitas Saham Jakarta Islamic Index (JII)

\begin{tabular}{|c|c|c|c|c|c|}
\hline No & KODE & Chi Square & Jarque Berra & Prob & Kesimpulan \\
\hline 1 & ASII & 9,48773 & 32,06987 & 0.0000 & Tidak Normal \\
\hline 2 & ICBP & 9,48773 & 100,9574 & 0.0000 & Tidak Normal \\
\hline 3 & TLKM & 9,48773 & 71,08373 & 0.0000 & Tidak Normal \\
\hline 4 & UNTR & 9,48773 & 108,0675 & 0.0000 & Tidak Normal \\
\hline 5 & UNVR & 9,48773 & 42,94836 & 0.0000 & Tidak Normal \\
\hline
\end{tabular}

Sumber: data diolah, Microsoft Excel

Tabel 8 merupakan rangkuman hasil dari uji normalitas pada saham-saham kombinasi portofolio optimal. Dapat dilihat bahwa hasil yang sama terjadi dengan saham-saham portofolio oprimal lainnya, yaitu pada ASII (32,06987), ICBP (100,9574), UNTR (108,0675), dan UNVR $(42,94836)$. Saham-saham tersebut memiliki nilai Jarque Berra $>$ nilai Chi Square 9,48773 serta keempatnya memiliki nilai probabilitas 0,000 yang juga mengartikan bahwa saham-saham tersebut juga berdistribusi tidak normal.

Berdasarkan hasil uji data yang tidak berdistribusi normal, diperlukan penyesuaian koreksi dengan menggunakan Cornish Fisher Expansion. Berikut pada tabel 9 merupakan tabel koreksi Cornish Fisher Expansion:

Tabel 9. Hasil koreksi Alpha Prime Saham Jakarta Islamic Index (JII)

\begin{tabular}{|c|c|c|c|}
\hline KODE & Koef Skewness & $\mathrm{a}(0.05)$ & $\alpha^{\prime}$ \\
\hline ASII & 0,277712 & 1,64485 & 1,565908905 \\
\hline ICBP & 0,399061 & 1,64485 & 1,531414814 \\
\hline TLKM & $-0,02553$ & 1,64485 & 1,652107037 \\
\hline UNTR & $-0,539413$ & 1,64485 & 1,798180979 \\
\hline UNVR & 0,233832 & 1,64485 & 1,578382026 \\
\hline
\end{tabular}




\section{Sumber: Data diolah, Microsoft Excel}

Hasil koreksi Cornish Fisher Expansion pada table 4.8 pada saham TLKM memiliki koefisien skewness -0.2553 dan mendapatkkan nilai penyesuaian alpha prime sebesar 1.652107037. Saham ASII memiliki koefisien skewness 0.277712 dan mendapatkkan sebesar 1.565908905. saham ICBP memiliki 0.399061 dan mendapatkan 1.531414814. saham UNTR memiliki koefisien skewness 0.539413 dan mendapatkkan nilai alpha prime sebesar 1.7981880979. Selanjutnya, saham UNVR memiliki 0.233832 dan mendapatkkan nilai alpha prime sebesar 1.578382026. Hasil koreksi dari Cornish Fisher Expansion ini selanjutnya akan dapat digunakan untuk melakukan sebuah perhitungan nilai $V$ alue at Risk (VaR) dari return harian saham dari saham-saham dengan kombinasi portofolio optimal dengan indeks Jakarta Islamic Index (JII).

\section{Uji Heteroskedastisitas}

Suatu varians saham dapat dilihat apakah bersifat konstan atau tidak yaitu dengan uji heteroskedastisitas. Pengukuran pada volatilitas saham apabila data saham bersifat homoskedastisitas hanya menggunakan VaR atau standar deviasi biasa. Apabila data nya bersifat heteroskedastisitas perhitungan ukuran volatilitasnya dapat dilakukan dengan model EWMA. Pengukuran dilihat dari probabilitas $\mathrm{F}$ stats apabila probabilitas $\mathrm{F}$ stats dilakukan perbandingan dengan critical value sebesar 5\%. Jika hasil data dari Probabilitas F stats $>5 \%$ maka data dikategorikan sebagai homokedastisitas. Jika Probabilitas F stats $<5 \%$ maka data dikategorikan sebagai heteroskedastisitas. Dengan menggunakan analisis dari Software eviews 9, berikut merupakan hasil pengukuran dari saham TLKM:

Tabel 10. Hasil Uji Heteroskedastisitas Saham TLKM

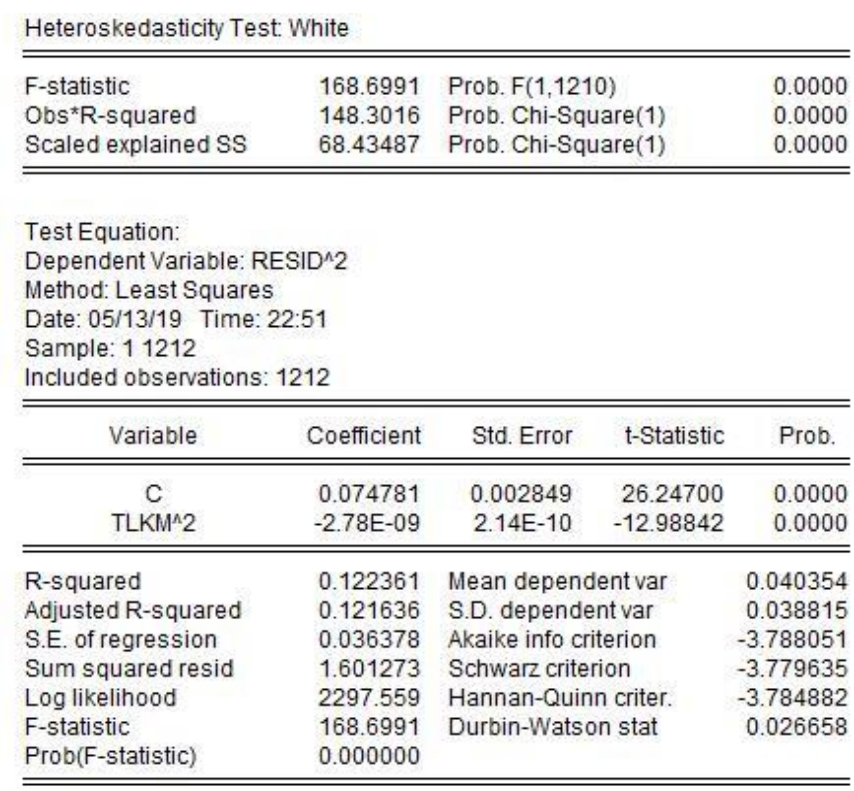

Berdasarkan hasil uji data dari saham kombinasi yang kedalam kombinasi portofolio dari optimal pada tabel 10 dibawah, untuk saham Jakarta Islamic Index (JII) dihasilkan kombinasi saham dari portofolio yang dinyatakan optimal tersebut memiliki nilai critical value sebesar 0,05 atau dapat diartikan jika sebuah Probabilitas F stats sebesar 0,000 berati dinyatakan lebih kecil. Dapat disimpulkan bahwa saham yang masuk ke dalam kombinasi portofolio yang dinyatakan optimal tersebut memiliki sifat heteroskedastisitas jadi dalam perhitungannya dari volatilitasnya menggunakan VaR dengan pendekatan EWMA.

Tabel 11. Hasil Uji Heteroskedastisitas Saham Jakarta Islamic Index (JII) 


\begin{tabular}{|c|c|c|c|c|c|}
\hline No & KODE & $\begin{array}{c}\text { Prob F } \\
\text { Stat }\end{array}$ & $\begin{array}{c}\text { Critical } \\
\text { Value }\end{array}$ & Hasil & Kesimpulan \\
\hline 1 & ASII & 0,0000 & 0,05 & 0,0000 & Heteroskedastisitas \\
\hline 2 & ICBP & 0,0000 & 0,05 & 0,0000 & Heteroskedastisitas \\
\hline 3 & TLKM & 0,0000 & 0,05 & 0,0000 & Heteroskedastisitas \\
\hline 4 & UNVR & 0,0000 & 0,05 & 0,0000 & Heteroskedastisitas \\
\hline 5 & UNTR & 0,0000 & 0,05 & 0,0215 & Heteroskedastisitas \\
\hline
\end{tabular}

Sumber: data diolah

Value at Risk (VaR) Pendekatan Exponentially Weighted Moving Average (EWMA)

Berdasarkan hasil pengujian dengan uji heteroskedastisitas diketahui bahwa saham-saham portofolio optimal pada Jakarta Islamic Index (JII) periode 2014-2018 bersifat heteroskedastisitas. Oleh karena itu, volatilitasnya dapat diukur dengan Exponentially Weighted Moving Average (EWMA) dengan tingkat kepercayaan $95 \%$ dan holding period selama 1 hari. Terdapat dua nilai yang digunakan sebagai acuan, yaitu asumsi nilai eksposur awal sebesar Rp100.000.000.

Tabel 12. Perhitungan VaR Single Instrument

(Nilai exposure: Rp100.000.000,00)

\begin{tabular}{|c|c|c|c|c|c|c|}
\hline No. & Kode & Nilai Exposure & Z Koreksi & $\sigma$ EWMA & $\mathrm{t}$ & VaR \\
\hline 1 & ASII & 100 juta & 1.5659089 & 0.012232568 & 1 & Rp1915508.784 \\
\hline 2 & ICBP & 100 juta & 1.53141481 & 0.023641763 & 1 & Rp3620534.618 \\
\hline 3 & TLKM & 100 juta & 1.65210704 & 0.016667472 & 1 & Rp2753644.697 \\
\hline 4 & UNTR & 100 juta & 1.79818098 & 0.009099244 & 1 & Rp1636208.723 \\
\hline 5 & UNVR & 100 juta & 1.57838203 & 0.026088436 & 1 & Rp4117751.859 \\
\hline
\end{tabular}

Sumber: data diolah Microsot Excel

Mengacu pada tabel 12 di atas, diketahui nilai VaR dalam rupiah dan VaR dalam presentase. Nilai VaR yang akan didapatkan investor apabila menanamkan uangnya sebesar Rp100.000.000,00 pada tanggal 29 Desember 2018 akan menerima nilai VaR seperti pada tabel di atas. Nilai VaR tertinggi didapatkan pada saham UNVR yakni senilai Rp 4.117.751, diikuti oleh ICBP sebesar Rp3.620.534, kemudian TLKM sebesar Rp2.753.644, ASII Rp 1.915.508 dan terakhir UNTR sebesar Rp1.636.208

Tabel 13. Perhitungan VaR Portofolio Optimal Jakarta Islamic Index (JII)

(Nilai exposure: Rp100.000.000,00)

\begin{tabular}{|c|c|cr|c|c|c|c|c|}
\hline No. & Kode & \multicolumn{2}{|c|}{ Nilai Exposure } & Z Koreksi & $\sigma$ EWMA & $\mathrm{t}$ & $\mathrm{t}$ & $\mathrm{VaR}$ \\
\hline 1 & $\mathrm{ASII}$ & $\mathrm{Rp}$ & 22092390 & 1.565908905 & 0.01223257 & $22.09 \%$ & 1 & Rp93490.947 \\
\hline 2 & ICBP & $\mathrm{Rp}$ & 232622 & 1.531414814 & 0.02364176 & $0.23 \%$ & 1 & Rp19.592 \\
\hline 3 & TLKM & $\mathrm{Rp}$ & 30870221 & 1.652107037 & 0.01666747 & $30.87 \%$ & 1 & Rp262414.237 \\
\hline 4 & UNTR & $\mathrm{Rp}$ & 16393614 & 1.798180979 & 0.00909924 & $16.39 \%$ & 1 & Rp43973.203 \\
\hline 5 & UNVR & $\mathrm{Rp}$ & 30411153 & 1.578382026 & 0.02608844 & $30.41 \%$ & 1 & Rp380825.426 \\
\hline \multicolumn{2}{|c|}{ Total } & \multicolumn{2}{c|}{$\mathrm{Rp} 100000000$} & & & $100.00 \%$ & & Rp780723.404 \\
\hline
\end{tabular}

Sumber: Data diolah Microsoft Excel

Mengacu pada hasil VaR, nilai tertinggi didapat oleh kode TLKM dengan bobot yang diterima yaitu 30.87\% dengan kerugian yang diterima maksimum TLKM menjadi Rp262.414 Selanjutnya saham UNVR bobot yang diterima 30.41\% memiliki kerugian yang diterima maksimum atau VaR sebesar Rp 380.825. Saham ASII bobot yang diterima 22.09\% memiliki nilai kerugian yang diterima maksimum sebesar Rp93.490. Selanjutnya ada UNTR dengan bobot 
16.39\% memiliki nilai kerugian yang diterima maksimum atau VaR sebesar Rp 43.973 dan terakhir saham ICBP bobot yang diterima $0.23 \%$ dan nilai kerugian yang diterima maksimum atau VaR Rp19.592.

\section{Uji Validitas VaR}

Setelah mengetahui nilai VaR harian, selanjutnya data akan duji dengan metode back testing dimana setiap data yang telah diketahui nilai Lose or Profit $(\mathrm{L} / \mathrm{P})$ akan dibandingkan dengan perhitungan VaR menggunakan volatilitasnya. Setiap data VaR yang lebih rendah dibandingkan dengan actual loss dapat dikatakan sebagai failure. Artinya VaR gagal memprediksi nilai risiko optimal yang didapatkan oleh investor pada hari tersebut. Penilaian Backtesting yang dilakukan oleh peneliti dilakukan dengan memberikan poin di tiap penilaian. Jika VaR berhasil maka akan dilambangkan dengan " 0 " dan jika VaR failure maka akandiberi tanda "1" unt mengetahui tingkat kegagalan dari VaR tersebut. Dengan tingkat kepercayaan 95\%, hasil pengujian data VaR dengan metode Back testing sebagai berikut:

Tabel 14. Pengujian Validitas VaR dengan Back-testing Saham JII

\begin{tabular}{|c|c|c|c|c|c|c|}
\hline Kode & $\mathrm{n}$ & $\mathrm{T}$ & $\mathrm{P}$ & $\mathrm{LR}$ & Critical Value & Hasil \\
\hline ASII & 1212 & 75 & 0,05 & 3,41039 & $<3.84$ & Valid \\
\hline ICBP & 1212 & 68 & 0,05 & 0,94259 & $<3.84$ & Valid \\
\hline TLKM & 1212 & 54 & 0,05 & 0,76148 & $<3.84$ & Valid \\
\hline UNTR & 1212 & 64 & 0,05 & 0,20935 & $<3.84$ & Valid \\
\hline UNVR & 1212 & 74 & 0,05 & 2,96959 & $<3.84$ & Valid \\
\hline
\end{tabular}

Sumber: Data diolah Microsoft Excel

Setelah dilakukan uji validitas dengan uji ini dan VaR tiap saham, berdasarkan hasil uji nya dinyatakan bahwa hasil dari uji back-testing secara valid. ASII memiliki nilai gagal atau failure sebesar 75 yang memiliki LR sebesar 3,41039, dinyatakan valid karena < Critical Value. ICBP memiliki nilai gagal atau failure sebesar 68 yang memiliki LR sebesar 0,94259, dinyatakan valid karena $<$ Critical V alue. TLKM memiliki nilai failure sebesar 54 yang memiliki nilai LR sebesar 0,076148, dinyatakan valid karena < Critical Value. UNTR memilki nilai failure sebesar 64 dengan LR sebesar $0.20935<$ Critical Value. Dan terakhir, untuk saham UNVR maka dinyatakan valid dengan nilai LR sebesar $2.96959<$ Critical Value. Dengan demikian, VaR dapat diprediksi nilai risiko maksimalnya pada hari x yang diterima oleh investor.

Hasil ukuran VaR pada portofolio akan dapat memberikan informasi tingkat dan nilai risiko yang akan diterima oleh investor atau calon investor di masa x. Jika VaR gagal dalam uji ini diperlukan evaluasi VaR berkelanjutan.

\section{Penutup}

Dengan menggunakan Model Indeks Tunggal terdapat 5 saham yang terseleksi dan membentuk portofolio optimal yaitu ASII, ICBP, TLKM, UNTR dan UNVR. Komposisi saham yang terbentuk dari pembentukan portofolio optimal dengan bobot saham adalah sebagai berikut ASII (22,09\%), ICBP (0.23\%), TLKM (30.87\%), UNTR (16.39\%), dan UNVR (30.41\%). Nilai risiko VaR dari Jakarta Islamic Index (JII) dengan Metode Value at Risk (VaR) pendekatan Exponentially Weighted Moving Average (EWMA) di konversikan ke dalam rupiah dengan holding period 1 hari dan asumsi investor menanamkan modalnya sebesar Rp100.000.000,00. Nilai VaR yang akan di dapat pada tanggal 29 Desember 2018 pada masing-masing saham ASII sebesar Rp93.490, ICBP sebesar Rp93.490, TLKM sebesar Rp262.414, UNTR sebesar Rp 43.973 dan UNVR sebesar Rp 380.825 . 
Bagi seorang investor dan calon investor, penelitian yang diteliti ini dapat dijadikan pertimbangan untuk membentuk sebuah portfolioi investasi dengan sebuah perhitungan metode indeks tunggal dan seleksi terhadap sekuritas benchmark Jakarta Islamic Index (JII). Selain itu, Investor diharapkan memilih risiko sesuai dengan preferensinya masing-masing, apakah investor yang Risk Averse, Risk. Neutral atau Risk. Seeker karena bisa menentukan tingkat risiko sekaligus keuntungan yang diharapkan. Selain itu, bagi calon investor atau investor muda dapat mempelajari alpha dan beta untuk strategi dalam berinvestasi. Bagi analisis, penelitian yang diteliti ini dapat diperdalam dengan melakukan seleksi menggunakan alat analisis lain yaitu, fundamental. Untuk penelitian selanjutnya, terdapat pengembangan penelitian dengan melakukan perbandingan dari beberapa portofolio optimal dan pada saham-saham yang mendeklarasikan diri sebagai perusahaan Syariah. Selain itu, dalam pembentukan ini dapat menggunakan perhitungan model lain terdapat Markowitz, Treynor, dalam pemilihan portofolio agar menghasilkan hasil yang lebih baik dan dapat dijadikan kombinasi portofolio yang lebih baik pula.

\section{Daftar Pustaka}

Buchdadi, Agung D. (2008). Perhitungan Value At Risk Portofolio Optimum Saham Perusahaan Syariah Dengan Pendekatan EWMA. Jurnal Akuntansi dan Keuangan Indonesia, Desember 2008, Vol. 5, No. 2, Hal. 182 - 201. 2008

Dian, dkk. (2014). Optimalisasi Pembentukan Portofolio Saham-Saham Indeks LQ-45 Perbandingan Model Exponentially Weighted Moving Average (EWMA) dan Model Generalised Autoregressive Conditional Heteroscedasticity (GARCH). Jurnal Akuntasi Pascasarjana Universitas Syiah Kuala.

Halim, Abdul. (2007). Analisis Investasi. Edisi ke-2. Jakarta: Salemba empat.

Huda, Nurul dan Mustafa Edwin Nasution. (2008). Investasi Pada Pasar Modal Syariah. Edisi Revisi Cetakan 2. Jakarta: Kencana

Husnan, Suad. (2005). Dasar-dasar Teori Portofolio dan Analisis Sekuritas. Edisi keempat. Yogyakarta: STIM YKPM.

Jogiyanto. (2013). Teori Portofolio dan Analisis Investasi Edisi 8. Yogyakarta: BPFE, Yogyakarta.

Tandelilin, Eduardus. (2010). Investasi dan Manajemen Portofolio. Yogyakarta : Kanisius. 